J. Asiat. Soc. Bangladesh, Sci. 46(1): 37-47, June 2020

\title{
MICROBIAL, PHYSICOCHEMICAL AND NUTRITIONAL QUALITY ASSESSMENT OF FRUIT JUICES IN TANGAIL MUNICIPALITY, BANGLADESH
}

\author{
SHAMIM ARA SHEAULI ${ }^{1}$, PRITAM SAHA $^{1}$, MD. YOUNUS MIA ${ }^{1 *}$, \\ REZUANA AFRIN ${ }^{1}$ AND SHAHIN MAHMUD ${ }^{2}$ \\ ${ }^{I}$ Department of Environmental Science and Resource Management, Mawlana Bhashani Science \\ and Technology University, Tangail, Bangladesh \\ ${ }^{2}$ Department of Biotechnology and Genetic Engineering, Mawlana Bhashani Science and \\ Technology University, Tangail, Bangladesh
}

\begin{abstract}
Analysis of the microbial, physicochemical and nutritional qualities of some commercially bottled and handmade fruit juices showed that total viable bacteria in bottle juices ranged from $9.6 \times 10^{7}$ to $2.0 \times 10^{11} \mathrm{cfu} / 100 \mathrm{ml}$ and handmade juices $1.3 \times 10^{5}$ to $9.6 \times 10^{7} \mathrm{cfu} / 100 \mathrm{ml}$. The log mean values of total bacteria count ranged from 9.14-10.19 $\mathrm{cfu} / 100 \mathrm{ml}$ (bottled) and 6.09-9.08 cfu/100 ml (handmade).Total coliform bacteria ranged from $0-7.6 \times 10^{9} \mathrm{cfu} / 100 \mathrm{ml}$ (bottled) and $0-2.8 \times 10^{5} \mathrm{cfu} / 100 \mathrm{ml}$ (handmade) with a range of log mean values of 3.18-6.95 cfu/100 ml (bottled) and 3.47-3.48 cfu/100 ml (handmade). The $\mathrm{pH}$ was acidic and mean value ranged from 3.14-4.03 for bottled juice and 3.72-3.73 (handmade). It was found that total soluble solids ranged from 10-11.33\% for bottle and $11.33-12.33 \%$ for handmade juices. The concentration of vitamin $\mathrm{C}$ in bottled and handmade juices ranged from $0.74-2.22 \mathrm{mg} / 100 \mathrm{ml}$ and $2.34-3.7 \mathrm{mg} / 100 \mathrm{ml}$, respectively, indicated that vitamin $\mathrm{C}$ content was very low. It was also revealed that quality of bottled and handmade juices was unsatisfactory and may not be useful for consumption. It is suggested that proper measure must be taken and manufacturing companies should develop the quality by maintaining hygiene and using good quality ingredients in preparing different types of juices.
\end{abstract}

Key words: Microbial, Physicochemical, Nutritional quality, Fruit juice

\section{Introduction}

Fruit juices are becoming an important part of the modern diet and considered to health and nutritional benefits in many communities. All over the world, in everyone's diet chart it is always included in different forms like as whole fruit, juice, beverage or still drink etc. Fruit juices are considered as a nutritious popular drink, but processed juice may not always be safe due to chemical hazards and microbial risks (Aneja et al. 2014). Nowadays, throughout the country people drink fruit juices without knowing actual safety and nutritional quality of these types of juices.

As a result they suffer from food borne and many other gastrointestinal diseases (Rashed et al. 2013). Microbial quality is very important in food since bacteria, fungi, viruses and

*Corresponding author: mdmia1998@gmail.com 
protozoa which are potential pathogens of human known to cause food borne diseases while cause for spoilage (Acharjee et al. 2013). The quality of fruit juices is strictly maintained in developed countries under several laws and regulations. Most fruit juices contain sufficient nutrients that could support microbial growth. In recent years, the increasing consumer awareness has emphasized the need for chemically and microbiologically safe food (Aneja et al. 2014). But in many developing and under-developed countries, the manufacturers are not conscious about the microbiological safety and hygiene of fruit juices because of lack of commitment and law enforcement system. Therefore, maintaining of the quality of processed fruit juices is an important concern. The chemical feature of juice considered in quality assessment include $\mathrm{pH}$, total soluble solids, acidity, ash content, ascorbic acid etc (Tasnim et al. 2010). It should also be noted that changes in $\mathrm{pH}$ could transform a food into one which supports pathogens to grow (FDA 2001, ICMSF 1989). In Bangladesh, the manufacturers are not concerned about the microbiological safety and hygiene of fruit juices due to lack of proper knowledge. Juices are frequently consumed by most of the people, so the quality of these juices should be known. Considering the importance, this study has been undertaken to assessing the physicochemical, nutritional and microbiological quality of bottled and handmade juices in Tangail municipality, Bangladesh.

\section{Materials and Methods}

Study area, time and collection of samples: The study was conducted at Tangail municipality, Bangladesh. A total of 18 juice samples of different brands and handmade of different producers were collected from three different locations, namely New bus stand, Old bus stand and Santosh, Tangail (Fig. 1). Twelve bottles (brand- 1 and 2) of orange and litchi juice samples were collected from street side shops and the handmade juice samples were collected from different fast food during January - May, 2018. Samples were transferred aseptically into the ice box with sufficient ice blocks.

Microbial analysis: Spread plate technique was performed for bacterial total plate count with serial dilution by following the standard procedure (APHA 1976). Plate count agar, MacConkey agar, were used for the growth of total viable bacteria, total coliform, respectively (Alam 2013). Colonies formed in the plates were counted by using digital colony counter after incubation at $37^{\circ} \mathrm{C}$ for 48 hours. The actual number of bacteria were 
estimated as colony forming unit (cfu/100 ml). The bacteria plate counts per $100 \mathrm{ml}$ per dilution were recorded using the following equation

$\begin{aligned} \text { Total count }= & \frac{\text { Total number of colonies }}{\text { Number of plates }} \times \frac{1}{\text { Dilution of actor }} \times \frac{1}{\text { Volume inoculated }} \\ & \text { ful } 100 \mathrm{ml} \text { (Bell } \text { et al. } 2005) .\end{aligned}$

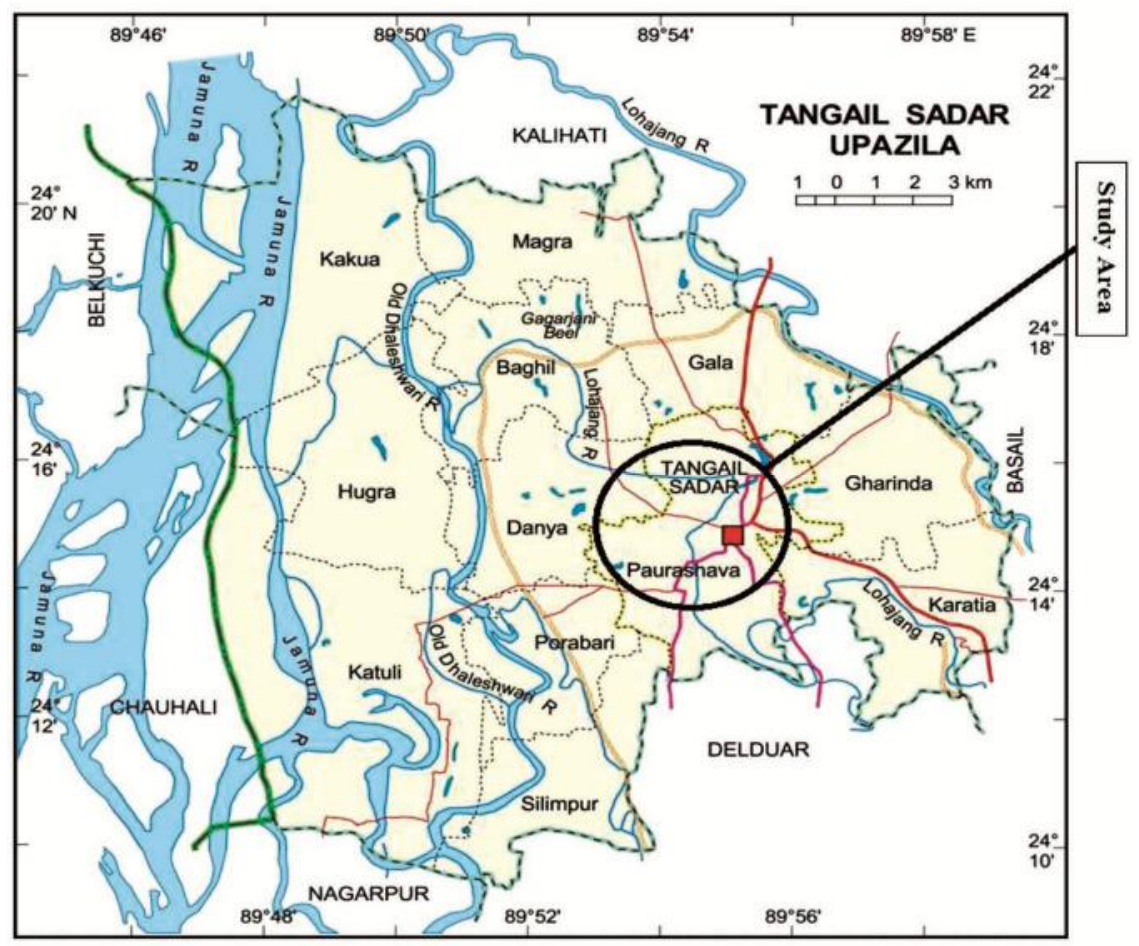

Fig.1. Map of the study area.

Physicochemical analysis: The $\mathrm{pH}$ was determined using digital $\mathrm{pH}$ meter. Total soluble solids (TSS) content of fruit juices was determined using an refractometer whereby a drop of pulp solution was placed on its prism. The percentage of TSS was obtained from direct reading of the refractrometer. Vitamin $\mathrm{C}$ was estimated by 2,6-dichlorophenolindophenol visual titration method according to AOAC (2004). The reagents used for the estimation of vitamin $\mathrm{C}$ were as follows: (i) Metaphosphoric acid (6\%), (ii) standard ascorbic acid solutions and (iii) 2, 6-dichlorophenolindophenol dye. For estimation of vitamin-C, the following steps were followed: Standardization of dye solution, preparation of solution and titration (AOAC 2004). 
Statistical analysis: MS Excel 2010 and SPSS 20 software were used for calculating average, standard deviation and preparation of graphs. Pearson's correlation coefficients were determined for analysis of correlation among the parameters.

\section{Results and Discussion}

\section{Microbial analysis}

Total viable count of bacteria: The range of total viable count was $2.0 \times 10^{11}$ to $9.6 \times 10^{7}$ $\mathrm{cfu} / 100 \mathrm{ml}$ in different brands of bottled juices at different locations. In bottled juices litchi (Pran) showed the highest value $\left(2.0 \times 10^{11} \mathrm{cfu} / 100 \mathrm{ml}\right)$ at New bus stand and the lowest value $\left(9.6 \times 10^{7} \mathrm{cfu} / 100 \mathrm{ml}\right)$ in Orange (Pran and BD Food) at both New and Old bus stand. The number of bacteria is very high because storage of products at refrigerator temperature or below is not always best for the maintenance of desirable quality of some fruits. Total viable count is shown in the graph as logarithm value.

The highest log of total viable count value was $11.505 \mathrm{cfu} / 100 \mathrm{ml}$ in litchi (BD food) at Old bus stand and the lowest Log total viable count value was $7.98 \mathrm{cfu} / 100 \mathrm{ml}$ in litchi (Pran) at New bus stand (Fig. 2). For handmade juices, the range of total viable count was $1.3 \times 10^{5}$ to $9.6 \times 10^{9} \mathrm{cfu} / 100 \mathrm{ml}$ at Tangail fast food and Santosh. In case of orange juice the highest value of total viable count was found at Santosh, and the lowest value was found in litchi juices at New bus stand.

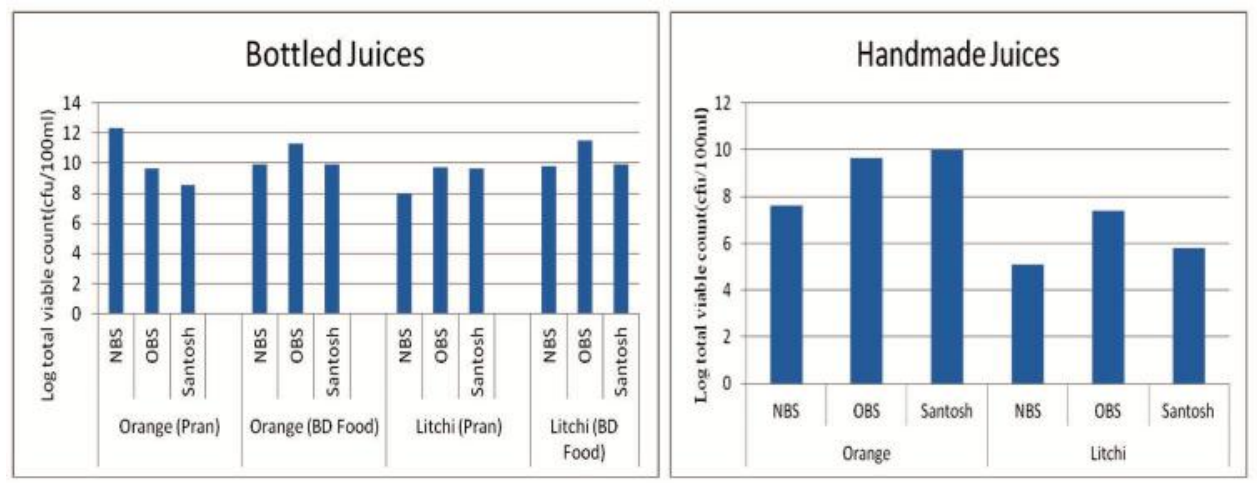

Fig. 2. Variation of total viable count of bacteria in different samples. NBS = New bus stand, OBS = Old bus stand.

The range of total viable count was $1 \times 10^{4} \mathrm{cfu} / \mathrm{ml}$ (Gulf Standard 2000). In other study it was reported that the highest total bacterial load $\left(2.66 \times 10^{6} \mathrm{cfu} / \mathrm{ml}\right)$ for packed fruit juice sample was found in an orange juice (sample P-12), collected from Farmgate, lemon $\left(3.94 \times 10^{5} \mathrm{cfu} / 100 \mathrm{ml}\right)$ and papaya $\left(1.98 \times 10^{6} \mathrm{cfu} / 100 \mathrm{ml}\right)$ from Mouchack, Dhaka, 
respectively (Rashed et al. 2013). Total viable bacterial count in most of the fresh juice samples was higher than the commercially packed juice, as the highest count was found as $2.4 \times 10^{4} \mathrm{cfu} / \mathrm{ml}$ and $3.2 \times 10^{3} \mathrm{cfu} / \mathrm{ml}$ in fresh and packed juice, respectively which was found to be lower than this study (Rahman et al. 2010). The load of viable bacteria in processed juice samples within the standard limit in the average of $10^{3} \mathrm{cfu} / \mathrm{ml}$ (Tasnim et al. 2010). Total viable count of commercially produced litchi juices in a range of $5 \times 10^{5}(\mathrm{cfu} / \mathrm{ml})$ and total vible count for handmade orange juices in a range of $1 \times 10^{5}$ $\mathrm{cfu} / \mathrm{ml}$ (Mortuza 2016). In a similar study, Fatema et al. (2016) estimated the total viable count of minerals in Allo vera, grapes and papaya. The highest total viable count ranged from $1.4 \times 10^{6}-1.2 \times 10^{6} \mathrm{cfu} / \mathrm{ml}$ was present in alovera and mango juice sample and lowest total viable count was present in papaya $9.0 \times 10^{5} \mathrm{cfu} / \mathrm{ml}$ and Malta $5.5 \times 10^{5} \mathrm{cfu} / \mathrm{ml}$.

All brands of processed juices exceed the standard limit of Gulf Standard (2000) in the present study. Total viable bacteria was found in high amount in these juices may be due to the unhygienic maintenance during preparation of the juices.

Total coliforms count (TCC): In this study, the range of total coliform bacteria was 0-7.6 $\times 10^{9} \mathrm{cfu} / 100 \mathrm{ml}$ in different brands of bottled juices at different locations. In bottled juices, the highest value $7.6 \times 10^{9} \mathrm{cfu} / 100 \mathrm{ml}$ was found in litchi (Pran) juices collected from New bus stand. The coliform count was nil in orange (Pran and BD Food) of Old bus stand and Santosh. The highest log total coliform count $11.38 \mathrm{cfu} / 100 \mathrm{ml}$ was found in litchi (BD Food) juices collected from Santosh (Fig. 3). On the other hand, for handmade juices, the range of total coliform count was $0-2.8 \times 10^{5} \mathrm{cfu} / 100 \mathrm{ml}$ at different locations. The highest value of total coliform count was found $\left(2.8 \times 10^{5} \mathrm{cfu} / 100 \mathrm{ml}\right)$ in litchi juices of Santosh and the total coliform count was nil in orange and litchi juices at different points.

The range of total coliform count is $1 \times 10^{2} \mathrm{cfu} / \mathrm{ml}$ (Gulf standard 2000). The presence of coliform in fruit juice is not allowed by safe food consumption standard (Andres et al. 2004). In another study, total coliform count for handmade lemon juices in a range of lemon $2.8 \times 10^{4} \mathrm{cfu} / \mathrm{ml}$ (Oranusi et al. 2012). Total coliform count found in litchi juices in a range of $4 \times 10^{2} \mathrm{cfu} / \mathrm{ml}$ and total coliform count for handmade orange juices in a range of $5 \times 10^{3} \mathrm{cfu} / \mathrm{ml}$ (Mortuza 2016).

In the present study it is showed that the total coliform was nil in some samples of bottled and handmade juices whereas some bottled and handmade juices exceeded the Gulf standard limit. This contamination could also be occurred due to lacking of proper quality control system for juice preparation, lacking of right storage conditions and bad packaging system (Kader et al. 2014). It is also found that the total coliform bacteria 
were found in high concentration of some juices due to unhygienic maintenance during prepraration of handmade juices.
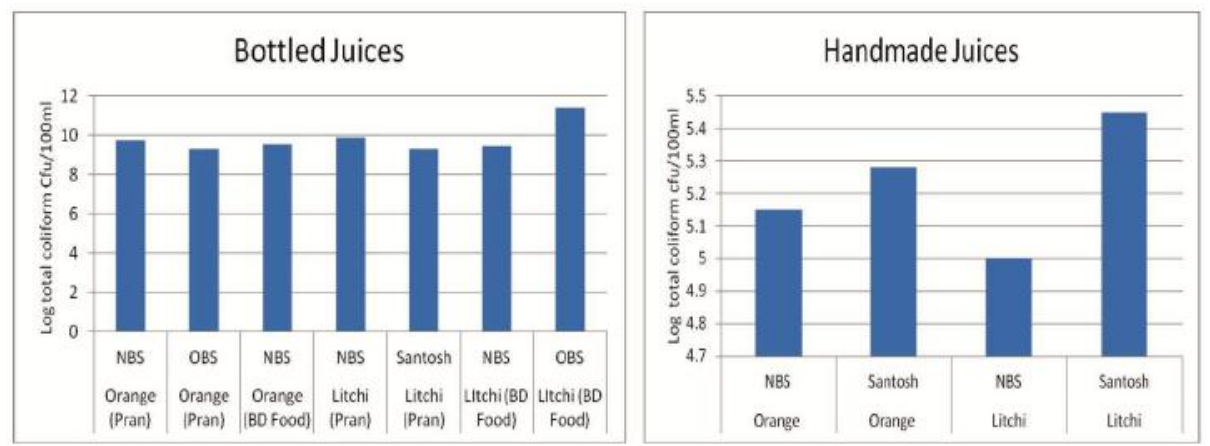

Fig. 3. Variation of total coliform count in different samples. NBS = New bus stand, OBS = Old bus stand.

\section{Physicochemical analysis}

pH: The highest $\mathrm{pH}$ (4.05) was found in litchi juice (Brand-1) in $200 \mathrm{ml}$ bottled and the lowest $\mathrm{pH}$ (3.03) was found in litchi juice (Brand-2), Fig. 4. On the other hand, for handmade juices the highest $\mathrm{pH}$ (3.8) was found in orange juices and the lowest $\mathrm{pH}$ (3.68) was found in litchi juices (Fig. 4). The highest $\mathrm{pH}$ was $5.45 \pm 0.09$ in papaya juices and the lowest of $\mathrm{pH} 2.40 \pm 0.07$ was in lemon juices.
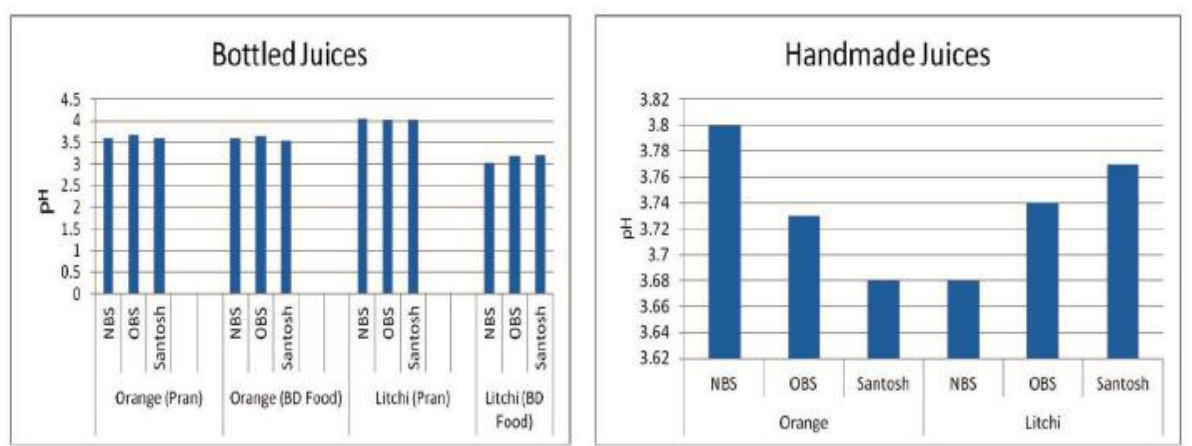

Fig. 4. Variation in concentrations of $\mathrm{pH}$ in different samples. $\mathrm{NBS}=\mathrm{New}$ bus stand, $\mathrm{OBS}=$ Old bus stand.

In other study, the $\mathrm{pH}$ for ripe mango juice was 3.4-4.8 (Anon. 1962). The mean $\mathrm{pH}$ value of total fruit juices was 4.9 with range of 3.88-5.71. The $\mathrm{pH}$ of both mango and papaya was 3.8 and 4.9, respectively and more acidic. FAO (2005) recommended value of $\mathrm{pH}$ for mango juice is 3.5-4.0. In present study authors have found that commercially 
bottled litchi juices of Brand-1 are slightly acidic than litchi juices of Brand-2 because Brand-1 (litchi) exceeded the standard limit (FAO 2005). This present study noted that $\mathrm{pH}$ values were within the standard limit.

Total soluble solids (TSS): The range of TSS was found from 10 to $12 \%$ for bottled juices and from 10 to $13 \%$ for handmade juices at different samples (Fig. 5). The highest TSS value was found in bottled (11.33\%) orange Brand-2 and litchi Brand-2 juices. On the other hand, highest TSS was $12.33 \%$ in orange handmade juices. The lowest concentration (10\%) was found in Brand-1 of orange and litchi bottled juices whereas, for handmade juices, lowest concentration of TSS (11.33\%) was found in litchi juices. The overall concentration of TSS of bottled juices was $11.33 \pm 0.58$ and for handmade juices was $12.33 \pm 0.58$. FAO (2005) estimated that TSS of bottled juices was $9.00 \pm 0.02$.
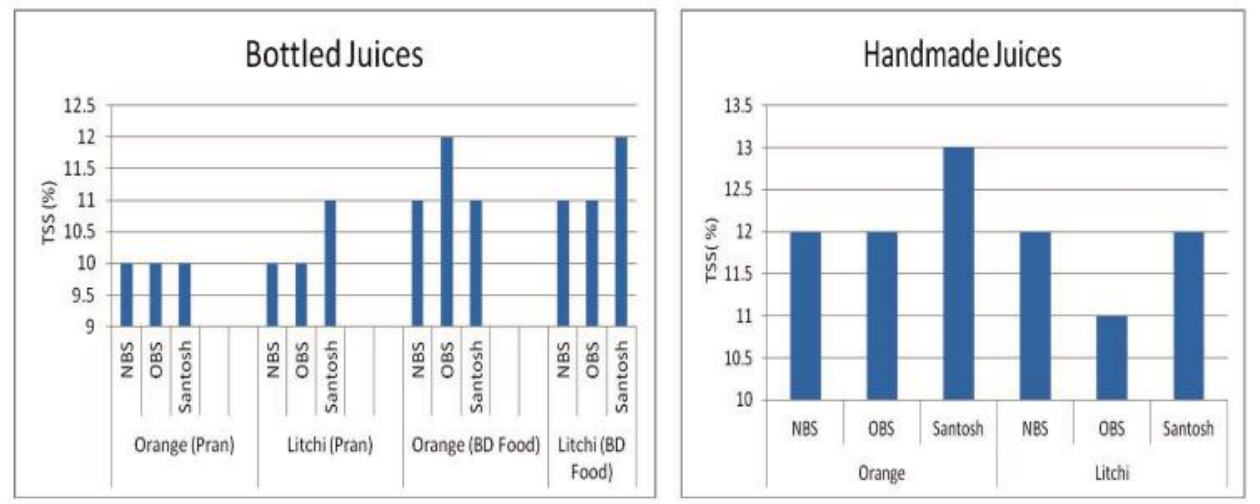

Fig. 5. TSS of different juice samples. NBS = New bus stand, OBS = Old bus stand.

The recommended value of TSS is $11.8 \%$ for orange (bottled) and $11.5 \%$ for papaya in handmade juices (Tasnim et al. 2010). According to Bangladesh standards specification for fruit or vegetables juice, Brix the TSS in fruit or vegetables juice is minimum (12\%). It may be said that TSS content in orange and litchi juices of Brand-1 in this study was comparatively lower than Brand-2 (bottled) and for handmade juices, TSS content in orange and papaya juices was comparatively higher than lemon and litchi juices. In 2001, FDA estimated that TSS of mango juices in a range of 11-13\% which are almost similar findings of FAO and FDA. The present study also found that TSS of orange and litchi juices (bottled) is similar to other studies. But TSS ranges of handmade juices such as orange, litchi, papaya are slightly higher than the standard level. It may be concluded that these fruits are mature and ripe that's why TSS crossed the standard limit. 


\section{Nutritional analysis}

Vitamin C: The range of concentration of vitamin $\mathrm{C}$ both for the bottled and handmade juices was from 0.74 to $2.22 \mathrm{mg} / 100 \mathrm{ml}$ and 1.1 to $4.1 \mathrm{mg} / 100 \mathrm{ml}$, respectively. In bottled juices, highest concentration of vitamin $\mathrm{C}(2.22 \mathrm{mg} / 100 \mathrm{ml})$ in Brand-1 and 2 (orange juice) and the lowest concentration of vitamin $\mathrm{C}(0.74 \mathrm{mg} / 100 \mathrm{ml})$ was found in Brand-1 and 2 (litchi juice) (Fig. 6). In case of handmade juices highest concentration of vitamin $\mathrm{C}(4.1 \mathrm{mg} / 100 \mathrm{ml})$ was found in orange juice and the lowest concentration of vitamin C $(1.1 \mathrm{mg} / 100 \mathrm{ml}$ ) was found in litchi juices (Fig. 6). In other study, Tasnim et al. (2010) estimated that vitamin $\mathrm{C}$ concentration of processed orange juice is $5.64 \pm 0.08$. Comparing between the nutritional analysis of vitamin $\mathrm{C}$ of bottled and handmade juices, it is assessed that highest concentrations of vitamin $\mathrm{C}$ are found in both for brand 1 (bottled) (orange, $2.22 \mathrm{mg} / 100 \mathrm{ml}$ ) and for handmade $(4.1 \mathrm{mg} / 100 \mathrm{ml}$ ) juces. In the present study, it is estimated that the amount of vitamin $\mathrm{C}$ in bottled juices is less than handmade juices.
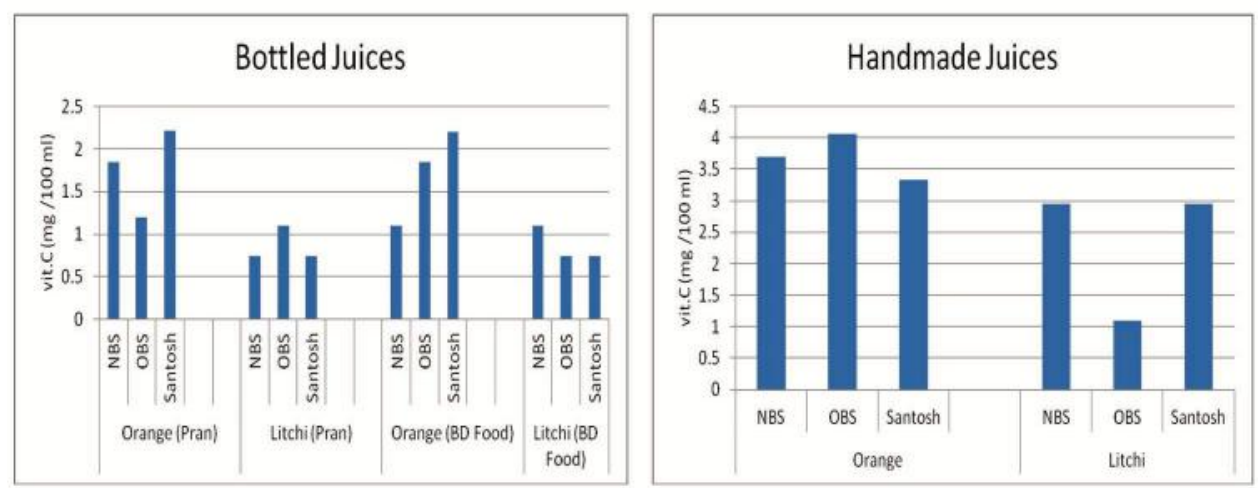

Fig. 6. Variation in concentrations of vitamin $\mathrm{C}$ in different samples. NBS = New bus stand, OBS = Old bus stand.

Correlation matrix among different microbial, physicochemical and nutritional parameters of fruit juices: Correlation matrix among the parameters was determined by Pearson's correlation coefficient along with their significant test (Table 1). Total viable count showed a negative corelation with $\mathrm{pH}$ and vitamin $\mathrm{C}$ and insignificant positive correlation with TSS and TCC. Total viable count, total coliform count, TSS had negative relation with $\mathrm{pH}$.

Correlation matrix among the parameters was determined by Pearson's correlation coefficient along with their significant test are given in Table 2. From the table there found that vitamin $\mathrm{C}$ showed positive relation with $\mathrm{pH}$, TSS, TVC and TCC but the 
relation is not significant $(\mathrm{p}>0.05)$. $\mathrm{pH}$ has positive correlation with vitamin $\mathrm{C}$ but negative relation with TSS, TVC and TCC. Total coliform count showed a positive relation with TSS and Vit. C and negative relation with $\mathrm{pH}$ and TVC.

Table 1. Correlation matrix among the microbial, physicochemical and nutritional parameters of bottle juices.

\begin{tabular}{lccccc}
\hline & $\mathrm{pH}$ & TSS & VIT-C & TVC & TCC \\
\hline $\mathrm{pH}$ & 1 & & & & \\
TSS & -0.521 & 1 & & & \\
Vit. C & 0.492 & -0.521 & 1 & & \\
TVC & -0.257 & 0.303 & -0.127 & 1 & \\
TCC & -0.258 & 0.038 & -0.252 & 0.073 & 1 \\
\hline
\end{tabular}

$\mathrm{TVC}=$ Total viable count, $\mathrm{TCC}=$ Total coliform count, $\mathrm{TSS}=$ Total soluble solids

Table 2. Correlation matrix among the microbial, physicochemical and nutritional parameters of handmade juices.

\begin{tabular}{lccccc}
\hline & $\mathrm{pH}$ & TSS & Vit C & TVC & TCC \\
\hline $\mathrm{pH}$ & 1 & & & & \\
TSS & -0.395 & 1 & & & \\
Vit. C & 0.054 & 0.681 & 1 & & - \\
TVC & -0.142 & 0.418 & 0.351 & 1 & \\
TCC & -0.008 & 0.618 & 0.323 & -0.352 & 1 \\
\hline
\end{tabular}

The results of the present study showed that, the juices were prepared and served in unhygienic environments, where a number of pathogenic microorganisms were found. However, while collecting juice samples, it was found that chopping board, knives, spoons, glass and jugs were also not frequently washed and a chance of cross contamination was also possible. Since juice samples, collected from different sampling sites of Tangail municipality were not satisfactory as total viable count, total coliform count were detected in large amount, so it could be hardly recommended that, consumption of commercially and handmade processed juices was safe. Most of the brands (bottled) and handmade juices exceeded the standard permissible in this study. Though the chemical parameters ( $\mathrm{pH}$, TSS) were within the recommended range, in some cases it exceeded the standard. From nutritional analysis, vitamin $\mathrm{C}$ was lower in bottled juices than the handmade juices. In respect to microbial, chemical and nutritional quality, 
these juices were not safe for human consumption. In the long run, people may suffer from different diseases such as diarrhea, vomiting, cholera, botulism, nausea etc. However, government health agencies must adopt measures to educate the producers on food safety and hygienic practices. Regular monitoring of the quality of fruit juices for human consumption must also be enforced by authority/law enforcement agencies.

\section{References}

Acharjee, M., K. Fatema, F. Jahan, J.S. Shanzida, M.A. Uddin and R. Noor. 2013. Prevalence of Vibrio cholerae in different food sample in the city of Dhaka, Bangladesh. Int. Food Res. J. 20(2): 1017-1022.

Alam, M. 2013. Microbial species diversity and hydrological effects on their occurrence at Karnaphuli river estuary. Agri. Sci. Res. J. 3:158-166.

Andres, S.C., L. Giannuzzi and N.E Zaritzky. 2004. The effect of temperature on microbial growth in apple cubes packed in film and preserved by use of orange juice. Int. J. Food Sci. Tech. 39(9): 927-933.

Aneja, K.R., R. Dhiman., N.K. Aggarwal, V. Kumar and M. Kaur. 2014. Microbes associated with freshly prepared juices of citrus and carrots. Int. J. Food Sci. 2014:408085.doi: 10.1155/2014/408085.

APHA (American Public Health Association). 1976. Standard Methods for the Examination of Water and Waste Water 14th Edition, American Public Health Association Inc., Washington DC.

Anonimous. 1962. pH values of food products. Food Eng. 34(3): 98-99.

AOAC (Association of Official Analytical Chemists). 2004. Official Methods of Analysis (20th ed.) USA, pp. 1058-1059.

Bell, A., P. Neaves and A.P Williams. 2005 Food Microbiology and Laboratory Practice, Oxford: Blackwell Science, UK, pp. 220-224.

Bridges, M.A., and M.R. Mattice. 1939. Over two thousand estimations of the $\mathrm{pH}$ of representative foods. Amer. J. Dig. Dis. 9: 440-449.

FDA (Food \& Drug Administration). 2001. Bacteriological Analytical Manual Online, pp. 1-6.

FAO (Food and Agriculture Organization of the United States). 2005. Codex general standard for fruit juices and nectars (Code Stan 247). Codex Alimentarius Commission, pp. 1-19.

Fatema K, S, Rahman, S. Ahmed and S. Datta. 2016 Microbiological Quality Assessment of handmade juice in street of the Dhaka city. Allergy Drugs Clin. Immunol. 1(1): 101.

Gulf Standard. 2000. Microbiological criteria for food stuffs, Part 1. GCC, Riyadh, Saudi Arabia.

ICMSF (International Commission on Microbiological Specification for Foods). 1989. Microorganism in Food 3: Microbial Ecology of Foods, Vol. 1. Factors affecting life and death of microorganisms, Academic Press, Orlando, p. 311.

Kader, M.M., A.A. Mamun, M.T. Islam and N. Sultana. 2014. Bacteriological analysis of some commercially packed and fresh fruit juices available in Jessore city, Bangladesh: A comparative look. Intl. J. Biosci. 5(1): 415-420.

Mortuza, T. 2016. Isolation and identification of microbes from various fruit juices made and sold for immediate consumption at home and in the market of Dhaka city. B.Sc. Dissertation, BRAC University, Dhaka.

Oranusi, U.S., W. Braide and H.O. Nezianya. 2012 Microbiological and chemical quality assessment of some commercially packed fruit juices sold in Nigeria. Greener J. Biol. Sci. 2(1): 1-6. 
Rahman, T., Hasan S. and Noor R. 2010. An assessment of microbiological quality of some commercially packed and fresh fruit juice, available in Dhaka city: A comparative study. Stamford J. Microbiol. 1(1): 13-18.

Rashed, N., M.A. Uddin, M.A. Haque, K.M. Saurab, A. Mrityunjoy and M. Majibur. 2013. Microbiological study of vendor and packed fruit juices locally available in Dhaka city, Bangladesh. Int. Food Res. J. 20(2): 1011-1015.

Tasnim, F., A.M. Hossain, S. Nusrath, K.M. Hossain M, D. Lopa and F.K.M. Haque. 2010. Quality assessment of industrially processed fruit juices available in Dhaka city, Bangladesh. Malaysian J. Nutri. 16(3): 431-438.

(Revised copy received on 18.03.2020) 